\title{
Dendritic cells' characteristics in patients with treated systemic lupus erythematosus
}

\author{
Anna Wardowska1凶, Żaneta Smoleńska², Katarzyna A. Lisowska³ ${ }^{3}$ Zbigniew Zdrojewski² and \\ Michał Pikuła'
}

'Laboratory of Tissue Engineering and Regenerative Medicine, Department of Embryology, Medical University of Gdansk, Gdańsk, Poland; ${ }^{2}$ Department of Internal Medicine, Connective Tissue Diseases and Geriatrics, Medical University of Gdansk, Gdańsk, Poland; ${ }^{3}$ Department of Pathophysiology, Medical University of Gdansk, Gdańsk, Poland

The systemic lupus erythematosus (SLE) is a chronic autoimmune disease related to a loss of immune tolerance against autoantigens that leads to tissue inflammation and organ dysfunction. Constant stimulation of dendritic cells (DC) with autoantigens is hypothesized to increase the B cells' activity which are involved in production of autoantibodies that play an essential role in the SLE development. We focused our study on detecting alterations in DCs at the cellular and molecular levels in patients with treated SLE, depending on the disease activity and treatment. In order to phenotype subpopulations of DCs, multicolor flow cytometry was used. Transcriptional changes were identified with quantitative PCR, while soluble cytokine receptors were assessed with the Luminex technology. We show that SLE patients display a higher percentage of activated myeloid DCs (mDCs) when compared to healthy people. Both, the mDCs and plasmacytoid DCs (pDCs) of SLE patients were characterized by changes in expression of genes associated with their maturation, functioning and signalling, which was especially reflected by low expression of regulatory factor ID2 and increased expression of IRF5. pDCs of SLE patients also showed increased expression of IRF1. There were also significant changes in the expression of $A P R I L$, $M B D 2$, and $E 2-2$ in $\mathrm{mDCs}$ that significantly correlated with some serum components, i.e. anti-dsDNA antibodies or complement components. However, we did not find any significant differences depending on the disease activity. While the majority of available studies focuses mainly on the role of pDCs in the disease development, our results show significant disturbances in the functioning of $\mathrm{mDCs}$ in SLE patients, thus confirming $\mathrm{mDCs}$ ' importance in SLE pathogenesis.

Keywords: systemic lupus erythematosus, disease activity, dendritic cells, gene expression, soluble cytokine receptors

Received: 07 July, 2020; revised: 12 July, 2020; accepted: 16 July, 2020; available on-line: 30 July, 2020

$\square_{\text {e-mail: anna.wardowska@gumed.edu.pl }}$

Acknowledgements of Financial Support: This research was funded by the National Science Centre, Poland, grant number 2012/05/D/NZ5/01224 granted to AW.

Abbreviations: SLE, systemic lupus erythematosus; SLEDAI, SLE disease activity index; DNMT, DNA Methyltransferase; MBD, Methyl-CpG Binding Domain Protein; APRIL, A proliferation-inducing ligand; BAFF, B-cell activating factor; IRF, interferon regulatory factor; PD-L, programmed death receptor ligand; TNFAIP, tumour necrosis factor (TNF)-a-induced protein; PBMC, peripheral blood mononuclear cell

\section{INTRODUCTION}

The systemic lupus erythematosus (SLE) is a chronic autoimmune disease related to a loss of immune tolerance against nuclear autoantigens that may lead to tissue inflammation and organ dysfunction. Even though the complex aetiology of this immune phenomenon is still under extensive investigation, scientists have managed to build a more concise view of SLE pathogenesis (Honarpisheh et al., 2018). Owing to that fact, dendritic cells (DCs) gained more interest in the autoimmunity field due to their ability to bridge the innate and adaptive immunity systems. These cells are widely believed to be a possible reason for the dysregulated "self - nonself" response. It has been hypothesized that the loss of self-tolerance to ubiquitous autoantigens in SLE results from high accessibility of these particles (Honarpisheh et al., 2018). Continuous stimulation of dendritic cells by autoantigens increases B cell activity, driving the autoreactive $\mathrm{B}$ cells to increase production of autoantibodies and pro-inflammatory cytokines, thus exacerbating the autoimmune process. DCs are a heterogeneous immune cell subpopulation, with two major subsets: myeloid DCs (mDCs) and plasmacytoid DCs (pDCs). Both subpopulations share their antigen-presenting characteristics but differ in terms of localization, function, and phenotype (Collin \& Bigley, 2018). In SLE, mDCs present autoantigens to $\mathrm{T}$ lymphocytes, whereas pDCs exert their impact on autoreactivity through production of IFN type I - a hallmark of human SLE severity (Chan et al., 2012; Henriques et al., 2012).

The cellular and molecular aspects of $\mathrm{mDCs}$ and pDCs engagement in SLE pathogenesis still remain elusive. Regardless of many years of studies on DCs' role in autoimmunity, gathered observations are controversial or even contradictory (Zeuner, 2003; Yu et al., 2010; Mackern-Oberti et al., 2015). Scientists agree with the hypothesis stating that $\mathrm{pDCs}$ are the major and primary trigger of SLE, due to excessive production of type I IFN and induction of type I interferon-regulated genes (Bennett et al., 2003; Macri et al., 2018; Sakata et al., 2018; van den Hoogen et al., 2018). The „IFN signature” is believed to induce hyperactivation of the immune responses and their autoaggressive mechanisms. The importance of pDCs is highlighted by considering them as a potential therapeutic target (Pellerin et al., 2015; Klavdianou et al., 2020). A monoclonal antibody targeting BDCA2 - BIIB059, a pDC-specific cell surface receptor, proved promising in treatment of skin manifestations of lupus, as its administration decreased expression of IFN response genes and ameliorated skin infiltrations (Furie et 
al., 2019). Currently, a phase II study evaluating the safety and efficacy of BIIB059 in SLE is in progress (Klavdianou et al., 2020). It seems that the role of $\mathrm{mDCs}$ in SLE induction and progression is underestimated. $\mathrm{mDCs}$ massively produce proinflammatory cytokines (i.e. TNF $\alpha$, IL6, etc. ) and aberrantly present autoantigens, thus driving autoreactivity of $\mathrm{T}$ and $\mathrm{B}$ cells.

The work presented here focuses on detecting alterations in DCs at the cellular and molecular levels, depending on activity of the disease and treatment present in SLE patients. Therefore, we analysed the frequency and activation state of DCs subsets using cytometric and molecular methods. We determined basic subpopulations of dendritic cells: $\mathrm{mDCs}$ and $\mathrm{pDCs}$, based on distinct expression of surface receptors: CD1c, CD11c, CD123, and CD303. Dendritic cells' gene expression was meticulously analysed with quantitative PCR to verify mRNA levels of genes required for their proper function and activation. To fulfil the picture, evaluation of soluble cytokine receptors in SLE patients' sera proved to be vital, especially regarding receptors for pro-inflammatory cytokines and growth factors.

\section{PATIENTS AND METHODS}

Patients. Blood samples were collected from 16 systemic lupus erythematosus patients, and 8 control subjects (healthy, with no history of autoimmune diseases). SLE patients were under monitoring and treatment at the Department of Internal Medicine, Connective Tissue Diseases and Geriatrics, Medical University of Gdansk, where they were diagnosed based on updated criteria of the American College of Rheumatology ( $\mathrm{Yu}$ et al., 2014) and positive results of the following immunologic parameters: anti-nuclear antibodies (ANA), anti-dsDNA antibodies, low serum levels of complement C3 and C4. Disease activity was measured with the SLE Disease Activity Index [SLEDAI] (Gladman et al., 2002; RomeroDiaz et al., 2011). Patients were divided into groups according to the acquired points: ACTIVE SLE >6, INACTIVE SLE $\leq 6$.

All participants were informed about the purpose of the tests and gave their written informed consent; the study has been approved by the Bioethics Committee for Scientific Research (consent number KBBN/188/2012, issued 22.05.2012) at the Medical University of Gdansk. All methods were performed by following relevant guidelines and regulations.

Based on clinical features (Table 1), patients were divided into two groups according to their disease activity status: - "inactive" or "remission" $(\mathrm{n}=8$, SLEDAI $2 \pm 1.85$, mean \pm S.D.), and "active" ( $\mathrm{n}=8$, SLEDAI 17.5 \pm 6.82 , mean \pm S.D.). Patients with ACTIVE SLE had a significantly higher level of anti-dsDNA antibodies (3.8-fold change, $p=0.0069$, Mann-Whitney U test) and lower C4 level ( $p=0.049$, Mann-Whitney U test) when compared with patients with INACTIVE SLE. Information about organ involvement was based on patient information collected during the examination. All of the patients were treated with either glucocorticoids, immunosuppressants or anti-inflammatory drugs. 8 patients with INACTIVE SLE were given glucocorticoids (e.g. prednisone, methylprednisone, mean daily dose: 0.5-1.0 $\mathrm{mg} / \mathrm{kg}$ ), 3 of them were treated with immunosuppressing drugs (e.g. azathioprine, cyclosporine, mycophenolatemofetil), and 2 of them took anti-malarial drugs (e.g. hydroxychloroquine). Patients with ACTIVE SLE were also given various combinations of these three therapeutics: 7 patients were treated with glucocorticoids (mean daily dose: $7.5 \mathrm{mg}$ - regardless of the body weight), 6 re-

Table 1. Clinical and laboratory characteristics of individuals enrolled in this study.

\begin{tabular}{|c|c|c|c|}
\hline & $\begin{array}{l}\text { ACTIVE SLE } \\
\mathrm{n}=8\end{array}$ & $\begin{array}{l}\text { INACTIVE SLE } \\
\mathrm{n}=8\end{array}$ & $\begin{array}{l}\text { Control group } \\
\mathrm{n}=8\end{array}$ \\
\hline Age (years) & $30(25-35,5)$ & $44.5(26,5-54.5)$ & $38(34,5-41.5)$ \\
\hline Sex (female/male) & $7 / 1$ & $6 / 2$ & $7 / 1$ \\
\hline SLE duration (year) & $7.5(1.5-11.5)$ & $13(2-15.5)$ & - \\
\hline SLEDAI (score) & $16(13-23)$ & $2(0-4)$ & - \\
\hline $\begin{array}{l}\text { Symptoms (organs affected): } \\
\text { Skin } \\
\text { Joints } \\
\text { Renal disorder } \\
\text { Neurologic } \\
\text { Immunologic } \\
\text { Antinuclearantibodies }\end{array}$ & $\begin{array}{l}6 \\
7 \\
5 \\
2 \\
8 \\
8\end{array}$ & $\begin{array}{l}6 \\
4 \\
4 \\
3 \\
7 \\
8\end{array}$ & - \\
\hline $\begin{array}{l}\text { Treatment: } \\
\text { Glucocorticoids } \\
\text { Immunosuppressant } \\
\text { Anti-malarial }\end{array}$ & $\begin{array}{l}7 \\
6 \\
5\end{array}$ & $\begin{array}{l}8 \\
3 \\
2\end{array}$ & - \\
\hline Anti- dsDNA antibodies (IU/ml) & $\begin{array}{l}368.855 \\
(204.425-532.575) * *\end{array}$ & $\begin{array}{l}96.5 \\
(23.34-172.325)\end{array}$ & $\mathrm{N} / \mathrm{A}$ \\
\hline C3 (g/l) & $0.755(0.71-0.87)$ & $0.985(0.855-1.29)$ & $\mathrm{N} / \mathrm{A}$ \\
\hline C4 (g/l) & $0.12(0.105-0.14) *$ & $0.2(0.155-0.225)$ & $\mathrm{N} / \mathrm{A}$ \\
\hline WBC $\left(10^{\wedge} 9 / \mathrm{I}\right)$ & $6.94(5-8.38)$ & $7.62(6.17-10.145)$ & $\mathrm{N} / \mathrm{A}$ \\
\hline Lymphocytes & $1.03(0.81-3.08)$ & $1.49(1.16-2.34)$ & $\mathrm{N} / \mathrm{A}$ \\
\hline CRP (mg/l) & $2.175(0.91-5.59)$ & $2.71(2.21-3.8)$ & $\mathrm{N} / \mathrm{A}$ \\
\hline Creatinine (mg/dl) & $0.69(0.56-0.92)$ & $0.835(0.57-0.92)$ & $\mathrm{N} / \mathrm{A}$ \\
\hline
\end{tabular}

Data are presented as median and quartiles (25-75). Statistical significance: ${ }^{*} p<0.05,{ }^{* *} p<0.001$ (Mann-Whitney $U$ test) in the comparison between active and inactive SLE. N/A - not acquired, these laboratory data were not collected for individuals from the control group. 
ceived immunosuppressants, and 5 - anti-malarial medications. None of the patients enrolled in this study were on a biological treatment in his/her disease history.

Determination of dendritic cells' subpopulations with flow cytometry. Flow cytometry staining and analysis of DCs were preceded by PBMCs (peripheral blood mononuclear cells) isolation using a Histopaque ${ }^{\mathrm{TM}}$ gradient (Sigma Chemical Co., USA). The phenotype and activation status of both subpopulations (myeloid and plasmacytoid) of DCs were examined. Anti-Human Lineage Cocktail 2 (Lin2) (CD3, CD14, CD19, CD20, CD56) (BD Pharmingen, USA) was used to eliminate lymphocytes, monocytes, eosinophils, and neutrophils from the flow cytometry analysis. Peripheral blood dendritic cells could be then distinguished from other leukocytes by their lack of staining with Lin2 (Lin2-). To obtain necessary data regarding DC subpopulations, the following antibodies were used: PerCP-Cy5.5-conjugated antiHLA-DR (clone LN3), PE-Cy7-conjugated anti-CD11c (clone 3.9), APC-conjugated anti-CD1c (clone L161), PE-conjugated anti-CD123 (clone 6H6), eFluor450-conjugated anti-CD303 (clone 201A) (eBioscience, Austria), PE-conjugated anti-CD80 (clone HB15e), and APCconjugated anti-CD83 (clone HB15) (Becton Dickinson,
USA). Based on the surface marker expression, the following subpopulations we identified: mDCs (HLA-DR, CD11c, CD1c), pDCs (HLA-DR, CD123, CD303), activated $\mathrm{mDCs}$ (HLA-DR, CD11c, CD80 hi, $\mathrm{CD} 83^{\mathrm{hi}}$ ), inactive mDCs (HLA-DR, CD11c, CD80º, CD83'o).

Magnetic isolation of mDCs and pDCs. Two populations of dendritic cells were isolated with a two-step magnetic isolation, starting from one sample of PBMCs. Myeloid DCs were isolated by two magnetic separation sets with CD1c (BDCA-1) ${ }^{+}$Dendritic Cell Isolation Kit (130-090-506, MiltenyiBiotec, USA), according to the manufacturer's instructions. First, B cells were depleted with CD19 MicroBeads. In the second step, CD1c (BDCA-1) ${ }^{+}$mDCs were indirectly magnetically labelled with anti-CD1c (BDCA-1)-Biotin and Anti-Biotin MicroBeads in the CD19-depleted flow-through fraction. Upon separation, the labelled CD1c (BDCA-1) ${ }^{+}$mDCs were retained within the column and eluted after removal of the column from the magnetic field. The unlabelled cells that were retrieved from this step were subsequently used for further isolation of pDCs. Plasmacytoid dendritic cells were then separated with the means of CD304 (BDCA-4/Neuropilin-1) MicroBead Kit (130090-532, MiltyneiBiotec, USA). First, the CD304+ cells

Table 2. Gene-specific primers and probe sets (Roche Assay ID) used in the experiment.

\begin{tabular}{|c|c|c|c|}
\hline Gene symbol & Assay ID & Name (alias) & Function \\
\hline HPRT1 & 145173 & $\begin{array}{l}\text { Hypoxanthine-guanine phosphoribosyl- } \\
\text { transferase }\end{array}$ & $\begin{array}{l}\text { Housekeeping gene; transferase in the purine salvage pa- } \\
\text { thway }\end{array}$ \\
\hline$P D-L 1$ & 104030 & $\begin{array}{l}\text { Programmed cell death } 1 \text { ligand } 1 \\
\text { (CD274) }\end{array}$ & $\begin{array}{l}\text { Surface receptor, key role in inhibition of the immune re- } \\
\text { sponse }\end{array}$ \\
\hline DNMT1 & 102318 & DNA methyltransferase 1 & $\begin{array}{l}\text { Transfers methyl groups to cytosine nucleotides of genomic } \\
\text { DNA, maintains methylation patterns following DNA repli- } \\
\text { cation }\end{array}$ \\
\hline ID2 & 102019 & Inhibitor of DNA binding 2 & Transcriptional regulator, an inhibitor of differentiation \\
\hline IFNG & 110609 & Interferon-gamma & Cytokine that induces a proinflammatory reaction \\
\hline IL-10 & 137154 & Interleukin 10 & $\begin{array}{l}\text { Cytokine with pleiotropic effects in immunoregulation and } \\
\text { inflammation }\end{array}$ \\
\hline IL-12A & 112242 & Interleukin 12 subunit alpha & Cytokine with a broad array of biological activities \\
\hline IL-1A & 100544 & Interleukin 1 subunit alpha & Proinflammatory cytokine \\
\hline IL-23A & 147435 & Interleukin 23 subunit alpha & Cytokine promoting cellular immunity \\
\hline IL-6 & 144013 & Interleukin 6 & $\begin{array}{l}\text { Cytokine functioning in inflammation and maturation of B } \\
\text { cells }\end{array}$ \\
\hline IRF1 & 144798 & Interferon regulatory factor 1 & $\begin{array}{l}\text { Transcriptional regulator, activator of genes involved in } \\
\text { both, the innate and acquired immune responses }\end{array}$ \\
\hline IRF5 & 103573 & Interferon regulatory factor 5 & $\begin{array}{l}\text { Transcription factor, immune system activator, known to } \\
\text { enhance SLE }\end{array}$ \\
\hline IRF8 & 116597 & Interferon regulatory factor 8 & $\begin{array}{l}\text { Transcription factor, regulator of B cells' differentiation, SLE } \\
\text { susceptibility gene, required for DCs development }\end{array}$ \\
\hline MBD2 & 115074 & Methyl-CpG binding domain protein 2 & $\begin{array}{l}\text { Nuclear protein, transcription repressor of methylated gene } \\
\text { promoters, role in gene silencing }\end{array}$ \\
\hline$E 2-2$ & 112749 & Transcription factor 4 (TCF4) & Transcription factor, essential to maintain pDCs phenotype \\
\hline TGFB1 & 101210 & Transforming growth factor beta 1 & $\begin{array}{l}\text { Multifunctional protein, regulates cell proliferation, differen- } \\
\text { tiation, and growth }\end{array}$ \\
\hline$T N F$ & 147880 & Tumor necrosis factor (TNF alpha) & $\begin{array}{l}\text { Multifunctional proinflammatory cytokine, cell proliferation, } \\
\text { differentiation, apoptosis, lipid metabolism, and coagulation }\end{array}$ \\
\hline TNFAIP3 & 111227 & TNF alpha-induced protein 3 (A20) & $\begin{array}{l}\text { Negative regulator of the immune response, inhibits NF- } \\
\text { kappa B activation, involved in the cytokine-mediated im- } \\
\text { mune and inflammatory responses }\end{array}$ \\
\hline TNFSF13 & 111225 & TNF superfamily member 13 (APRIL) & $\begin{array}{l}\text { Proliferation inducing ligand, vital for survival and differen- } \\
\text { tiation of B cells }\end{array}$ \\
\hline TNFSF13B & 104221 & TNF superfamily member 13b, (BAFF) & $\begin{array}{l}\text { B cell-activating factor, vital for survival and differentiation } \\
\text { of B cells }\end{array}$ \\
\hline
\end{tabular}


Table 3. Serum concentration of soluble cytokine receptors in all study populations.

\begin{tabular}{|c|c|c|c|c|}
\hline & $\begin{array}{l}\text { Control } \\
(\mathrm{pg} / \mathrm{ml})\end{array}$ & $\begin{array}{l}\mathrm{SLE} \\
(\mathrm{pg} / \mathrm{ml})\end{array}$ & $\begin{array}{l}\text { INACTIVE SLE } \\
(\mathrm{pg} / \mathrm{ml})\end{array}$ & $\begin{array}{l}\text { ACTIVE SLE } \\
(\mathrm{pg} / \mathrm{ml})\end{array}$ \\
\hline sEGFR & $\begin{array}{l}41234.5 \\
(39545.0-42934.0)\end{array}$ & $\begin{array}{l}34580.0 \\
(26394.0-55952.0)\end{array}$ & $\begin{array}{l}38639.0 * \\
(31850.0-55952.0)\end{array}$ & $\begin{array}{l}31922.0 \\
(26394.0-41891.0)\end{array}$ \\
\hline sgp130 & $\begin{array}{l}133218.0 \\
(123345.0-143082.0)\end{array}$ & $\begin{array}{l}132953.0 \\
(72328.0-206900.0)\end{array}$ & $\begin{array}{l}122417.0 \\
(100085.0-206900.0)\end{array}$ & $\begin{array}{l}138854.5 \\
(72328.0-167595.0)\end{array}$ \\
\hline sIL-1RII & $\begin{array}{l}4309.0 \\
(4120.0-4498.0)\end{array}$ & $\begin{array}{l}4886.0 \\
(690.0-8396.0)\end{array}$ & $\begin{array}{l}2757.0 \\
(690.0-8169.0)\end{array}$ & $\begin{array}{l}4949.0 \\
(1196.0-8396.0)\end{array}$ \\
\hline sIL-1Ra & $\begin{array}{l}322.1 \\
(287.6-356.6)\end{array}$ & $\begin{array}{l}677.0 \\
(127.5-1550.0)\end{array}$ & $\begin{array}{l}609.6 \\
(207.0-1550.0)\end{array}$ & $\begin{array}{l}722.8 \\
(127.5-1183.0)\end{array}$ \\
\hline sIL-4R & $\begin{array}{l}341.1 \\
(269.3-413.0)\end{array}$ & $\begin{array}{l}397.8 \\
(164.79-2691.0)\end{array}$ & $\begin{array}{l}343.1 \\
(294.4-741.3)\end{array}$ & $\begin{array}{l}585.3 \\
(164.79-2691.0)\end{array}$ \\
\hline sIL-6R & $\begin{array}{l}13673.5 \\
(11598.0-15749.0)\end{array}$ & $\begin{array}{l}16555.0 \\
(9971.0-26788.0)\end{array}$ & $\begin{array}{l}18782.0 \\
(9971.0-26788.0)\end{array}$ & $\begin{array}{l}15829.0 \\
(12628.0-23151.0)\end{array}$ \\
\hline sRAGE & $\begin{array}{l}66.8 \\
(0.0-133.6)\end{array}$ & $\begin{array}{l}68.3 \\
(16.95-265.0)\end{array}$ & $\begin{array}{l}44.5 \\
(31.7-252.3)\end{array}$ & $\begin{array}{l}83.7 \\
(16.95-265.0)\end{array}$ \\
\hline sTNFRI & $\begin{array}{l}705.7 \\
(676.3-735.1)\end{array}$ & $\begin{array}{l}1109.0 \\
(507.22-2488.0)\end{array}$ & $\begin{array}{l}1187.0 \\
(979.1-1624.0)\end{array}$ & $\begin{array}{l}1020.5 \\
(507.22-2488.0)\end{array}$ \\
\hline sTNFRII & $\begin{array}{l}3573.5 \\
(3299.0-3848.0)\end{array}$ & $\begin{array}{l}5430.0 \\
(2804.0-11219.0)\end{array}$ & $\begin{array}{l}5430.0 \\
(4503.0-8659.0)\end{array}$ & $\begin{array}{l}5939.0 \\
(2804.0-11219.0)\end{array}$ \\
\hline sVEGFR1 & $\begin{array}{l}346.7 \\
(311.5-382.0)\end{array}$ & $\begin{array}{l}457.6 \\
(0.0-2605.0)\end{array}$ & $\begin{array}{l}457.6 \\
(0.0-711.4)\end{array}$ & $\begin{array}{l}265.3 \\
(0.0-2605.0)\end{array}$ \\
\hline sVEGFR3 & $\begin{array}{l}378.0 \\
(352.2-403.9)\end{array}$ & $\begin{array}{l}403.9 \\
(208.82-2331.0)\end{array}$ & $\begin{array}{l}403.9 \\
(208.8-741.1)\end{array}$ & $\begin{array}{l}432.0 \\
(208.82-2331.0)\end{array}$ \\
\hline
\end{tabular}

Levels of the soluble cytokine receptors in serum collected from SLE patients were assessed with the Luminex ${ }^{\circledast} \mathrm{xMAP}^{\circledR}$ technology. Data were collected by Luminex MAGPIX ${ }^{\circledR}$ Analyzer and analysed with xPONENT 4.2 software. Data are presented as median and quartiles (25-75). Statistical significance: ${ }^{*} p<0.05$ (Mann-Whitney $\mathrm{U}$ test) in the comparison between active and inactive SLE.

were magnetically labelled with anti-CD304 MicroBeads. Then, the cell suspension was loaded onto a column and placed in the magnetic field. After removal of the column from the magnetic field, the magnetically retained CD $304^{+}$pDCs were eluted as the positively selected cell fraction. The purity of $\mathrm{mDCs}$ and $\mathrm{pDCs}$, as determined by flow cytometry, was high $(>95 \%)$.

Analysis of gene expression in DCs using quantitative PCR. RNA was isolated using the miRNeasy Mini Kit (Qiagen, Germany) according to the manufacturer's protocol. Quality and concentration of samples were evaluated using an Epoch Spectrophotometer (Bio-Tek, USA). Total RNA was reverse transcribed into cDNA with iScript cDNA Kit (Bio-Rad, USA). For dendritic cells, evaluation of 19 activity-associated transcripts was conducted with Locked Nucleic Acid probes from the Universal Probe Library - UPL (Roche GmbH Diagnostics, Germany). Real-time PCR was performed using the LightCycler 480 Probe Master Kit (Roche Diagnostics $\mathrm{GmbH}$, Mannheim, Germany) and the Light Cy$\operatorname{cler}^{\circledR} 96$ PCR System (Roche). Reactions were prepared in a total volume of $10 \mu \mathrm{l}$. The cycling conditions for UPL reactions were as follows: one cycle of $95^{\circ} \mathrm{C}$ for $10 \mathrm{~min}$ (initial denaturation), 45 cycles of $95^{\circ} \mathrm{C}$ for $10 \mathrm{~s}$ (denaturation) and $60^{\circ} \mathrm{C}$ for $30 \mathrm{~s}$ (annealing). The rela- tive quantification method was applied for data analysis, and HPRT1 (hypoxanthine-guanine phosphoribosyltransferase) house-keeping gene expression was used as a reference. Gene-specific primers and probe sets (Roche Assay ID) used in the experiment are listed in Table 2. Expression levels were determined by using the $2-\Delta \Delta \mathrm{Ct}$ method relative to the reference gene - HPRT1.

Determination of soluble receptors for cytokines. For soluble cytokine receptors in the serum collected from SLE patients, Luminex ${ }^{\circledR}$ xMAP $^{\circledR}$ technology was used. This is a powerful platform for multiplex detection of proteins in a single biological sample. For analysis of SLE serum, we used Human Soluble Cytokine Receptor Magnetic Bead Panel (Merck Millipore, Germany) which enables simultaneous quantification of the following: soluble epidermal growth factor receptor (sEGFR), soluble glycoprotein 130 (sgp130), soluble interleukin-1 receptor type I (sIL-1RI) and type II (sIL-1RII), soluble interleukin-2 receptor alpha (sIL-2R $\alpha)$, soluble receptors for IL-4 (sIL-4R) and IL-6 (sIL-6R), soluble receptor for advanced glycation end products (sRAGE), soluble tumour necrosis factor receptor type I (sTNFRI) and type II (sTNFRII), soluble vascular endothelial growth factor receptor 1 (sVEGFR1), 2 (sVEGFR2), and 3 (sVEGFR3). Serum samples were thawed on ice. The procedure was 

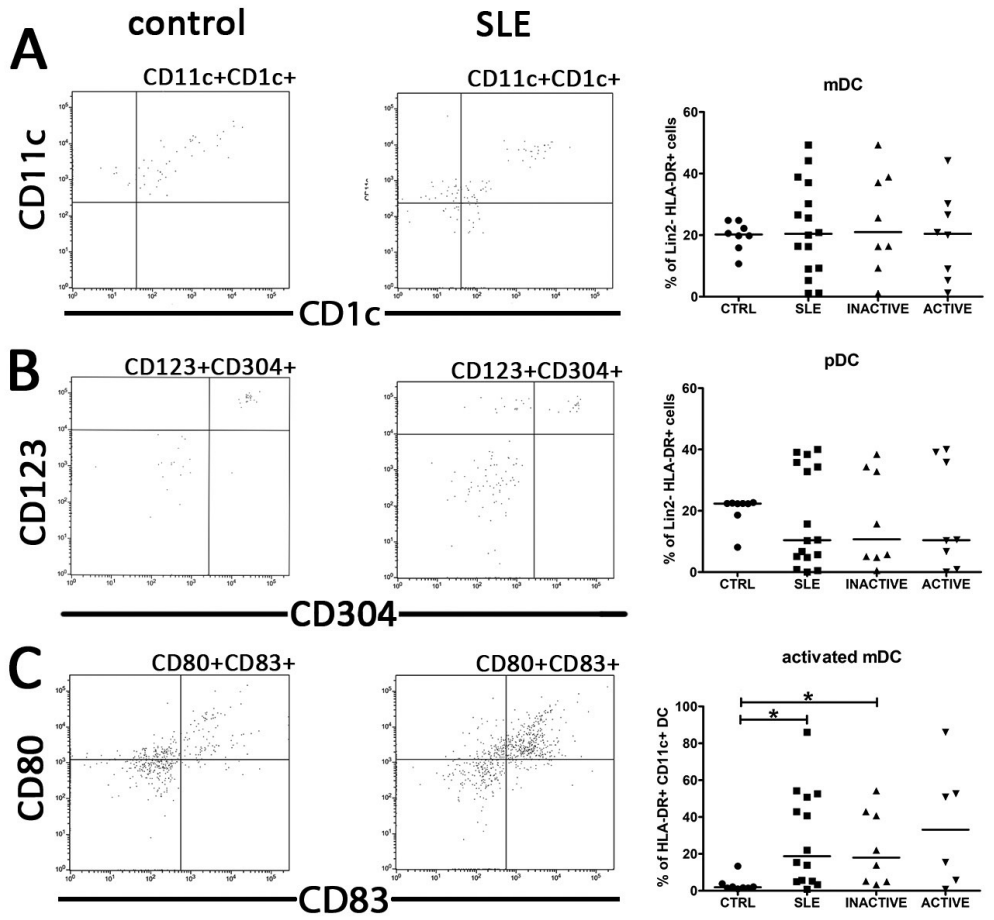

Figure 1. Alterations in dendritic cell subpopulations and their activity in SLE patients.

Panel A shows representative dot plots (gated on Lin2-HLA-DR+ cells) of peripheral mDCs (CD11c+CD1c+ cells) from a healthy person (left) and a patient with SLE (right). The graph shows comparison of $\mathrm{MDC}$ percentages between control group (CTRL), total number of SLE patients and patients divided into groups based on the disease activity (INACTIVE SLE or ACTIVE SLE). Panel B shows flow cytometry presentation of peripheral blood pDCs (CD123+CD304+ cells) of control (left) and a SLE patient (right), and comparison of percentages of pDCs in all analysed groups. Panel C demonstrates a dot plot presentation of flow cytometry analysis of mDCs' activation. Activated mDCs were identified as CD80+CD83+ cells, both in the control person (left) and SLE affected patient (right). (A-C) Data were collected with BD FACS LSRFortessa flow cytometer and analysed with FACSDiva software. Graphic presentation of the results was prepared with FCSalyser https://sourceforge.net/projects/fcsalyzer/). Data in graphs represent individual distribution of data points and median value per group. Significance was calculated in relation to the control group, ${ }^{*} p<0.05,{ }^{* *} p<0.001,{ }^{* * *} p<0.0001$ (Mann-Whitney U Test).

done according to the manufacturer's instructions. Briefly, sera were incubated with a mixture of color-coded beads, pre-coated with analyte-specific capture antibodies. Next, a cocktail of biotinylated detection antibodies specific to the analyte of interest was added, followed by the addition of phycoerythrin (PE)-conjugated streptavidin which binds to the detection antibodies. The prepared samples were read by Luminex MAGPIX ${ }^{\circledR}$ Analyzer (Merck Millipore, Germany). Data were analysed using xPONENT 4.2 software and finally presented as $\mathrm{pg} / \mathrm{ml}$ in Table 3.

Analysis and Statistics. All flow cytometry analyses were performed with BD FACS LSRFortessa flow cytometer (BD USA), using BD FACSDiva software (BD Bioscience, USA). The acquisition gates were restricted to lymphocytes based on morphological characteristics (forward versus side scatter) and 50000 cells were acquired and analysed. Statistical analysis was performed using Statistica 12.0 (StatSoft Inc., Tulsa, Oklahoma, USA). Data are presented as medians and 25-75 quartile ranges unless otherwise stated. Comparison of parameters between all groups (control/SLE patients/INACTIVE SLE patients/ACTIVE SLE patients) was made with the Kruskal-Wallis ANOVA test, and between two groups with the Mann-Whitney U test. Associations between the groups were evaluated with Spearman Rank Correlation test. Results of correlation analyses are presented as correlation coefficients. Statistical significance was accepted when $p$ was $\leq 0.05$. Graphs were prepared either with Statistica v.12 or GraphPad Prism 5 (GraphPad Software, La Jolla, USA).

\section{RESULTS}

\section{Percentages of circulating DC subpopulations in patients with SLE}

The distinction between two subpopulations of dendritic cells was based on the expression of surface markers characteristic for either myeloid or plasmacytoid DCs. Cells expressing CD3, CD14, CD19, CD20, and CD56 $\left(\operatorname{Lin} 2^{+}\right)$were ruled out of the analysis, as representatives of other immune cell compartments. The percentages of mDCs $\left(\mathrm{CD} 11 \mathrm{c}^{+} \mathrm{CD} 1 \mathrm{c}^{+}\right.$cells) in patients with SLE, regardless of the disease activity, were comparable to the values observed for control individuals (Fig. 1A). Even though the percentage of pDCs $\left(\mathrm{CD} 123^{+} \mathrm{CD} 303^{+}\right.$cells) exhibited a slight decline in SLE patients in comparison to the control group (Fig. 1B), no significant differences were found in the proportion of these cells between the studied groups.

To evaluate activation and maturation of the analysed DC subpopulations, we assessed expression of two surface proteins (CD80 and CD83), referred to as activation and antigen presentation capability markers. We observed a remarkable increase in the percentage of $\mathrm{mDCs}$ with expression of both, CD80 and CD83, in all SLE patients when compared to control subjects ( $p=0.043$, Mann-Whitney U test) (Fig. 1C). When taking disease activity status into consideration, there was a significant difference between patients with INACTIVE SLE and control group ( $p=0.002$, Mann-Whitney $U$ test). At the 

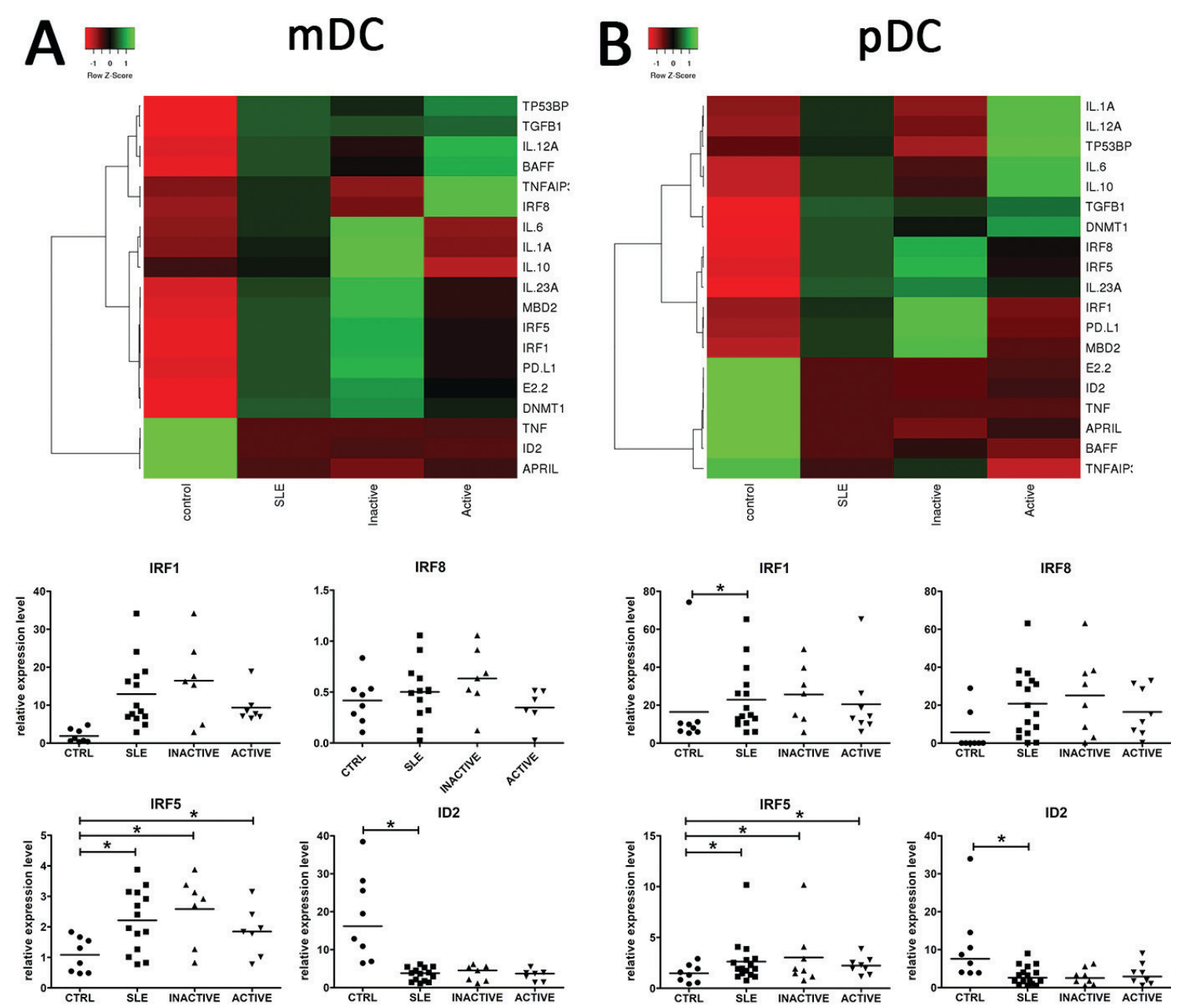

Figure 2. Transcriptional changes in $\mathrm{mDCs}$ and $\mathrm{pDCs}$ in SLE.

Panel A shows a row scaled clustering heat map according to Pearson correlation of differentially expressed genes in mDCs between control volunteers and SLE samples (left upper panel). Statistically significant changes in expression levels of IFR1, IRF5, IRF8 and ID2, relative to HPRT (hypoxanthine-guanine phosphoribosyltransferase), were determined by qPCR (left bottom panel). Panel B shows a heatmap of $\mathrm{pDCs}$ gene expression comparison between the control and SLE groups (right upper panel). The expression levels of IFR1, IRF5, IRF8, and ID2, related to HPRT expression in PDCs, were determined by QPCR (right bottom panel). Heat map color-coding: green (upregulated), red (downregulated) and black (no modulation); data are presented as median value from each of the analysed group. Data in graphs represent individual distribution of data points and median value per group. Significance was calculated in relation to the control group, ${ }^{*} p<0.05,{ }^{* *} p<0.001,{ }^{* * *} p<0.0001$ (Mann-Whitney U Test).

same time, the percentage of inactive DCs (without the CD80 and CD83 antigens) was significantly decreased in SLE patients when compared to healthy people ( $p=0.002$, Mann-Whitney U test, data not shown).

\section{Expression of regulatory factors in $\mathrm{mDCs}$ and $\mathrm{pDCs}$ from SLE patients}

Next, we analysed gene expression of regulatory factors in both subpopulations of magnetically separated DCs, as described in the Patients and Methods section. We focused on a selected set of genes associated with the generation, functioning and signalling of each DC subpopulation (Table 2).

Analysis of the gene expression profile revealed significant changes in dendritic cells acquired from SLE patients, regardless of the disease severity (Fig. 2). Among the upregulated transcripts were members of the interferon-regulatory factor (IRF) protein family, known as transcriptional regulators of the type I interferon signature (Wu and Assassi, 2013). mDCs from SLE patients showed an increased expression of IRF5 $(\mathrm{p}=0.008$
Mann-Whitney U test, Fig. 2A). Also, we saw an increasing trend in expression of IRF/in mDCs (Fig. 2A).

Meanwhile, $\mathrm{pDCs}$ from SLE patients demonstrated upregulation of the IRF1 transcript $(p=0.032$, MannWhitney $\mathrm{U}$ test, Fig. 2B). IRF8, a transcription factor primarily known for its role in $\mathrm{pDC}$ development and function, was moderately upregulated in SLE patients when compared to the control group (Fig. 2B). We also noted a significant decrease in the transcript level of ID2 (inhibitor of DNA binding 2) in both subpopulations from SLE patients (Fig. 2).

Other analysed transcripts were related to the epigenetic status of cells. Expression of TNFSF13 (APRIL) also presented altered expression in SLE patients - it was significantly decreased only in mDCs $(p=0.013$, Mann-Whitney U test, Fig. 3). We also observed changes in the expression profile of genes related to regulation of the immune response. E2-2, vital for maintenance of pDC phenotype, was significantly increased only in mDCs from SLE patients $(p=0.0003$, Mann-Whitney U test, Fig. 3). 

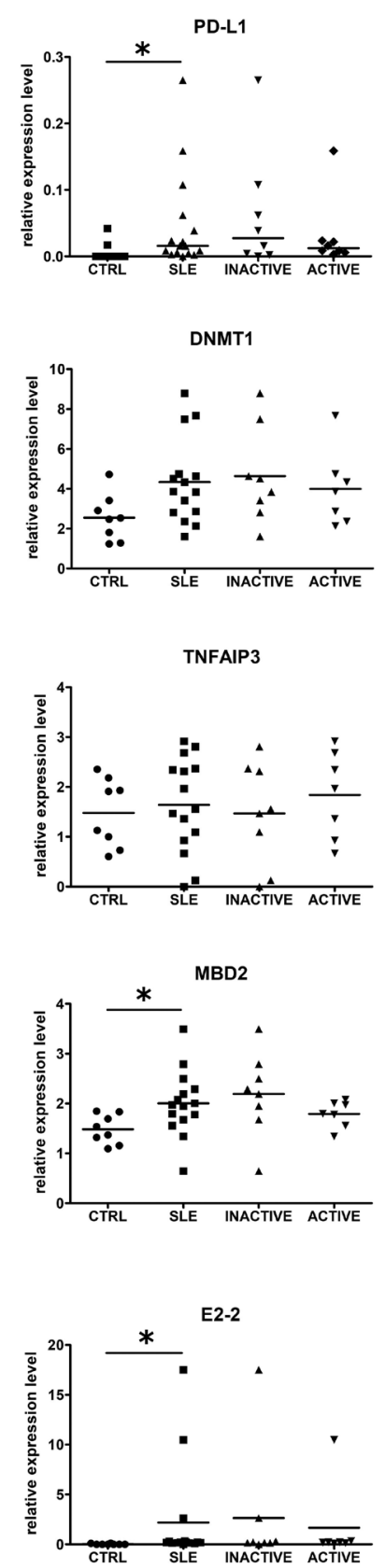
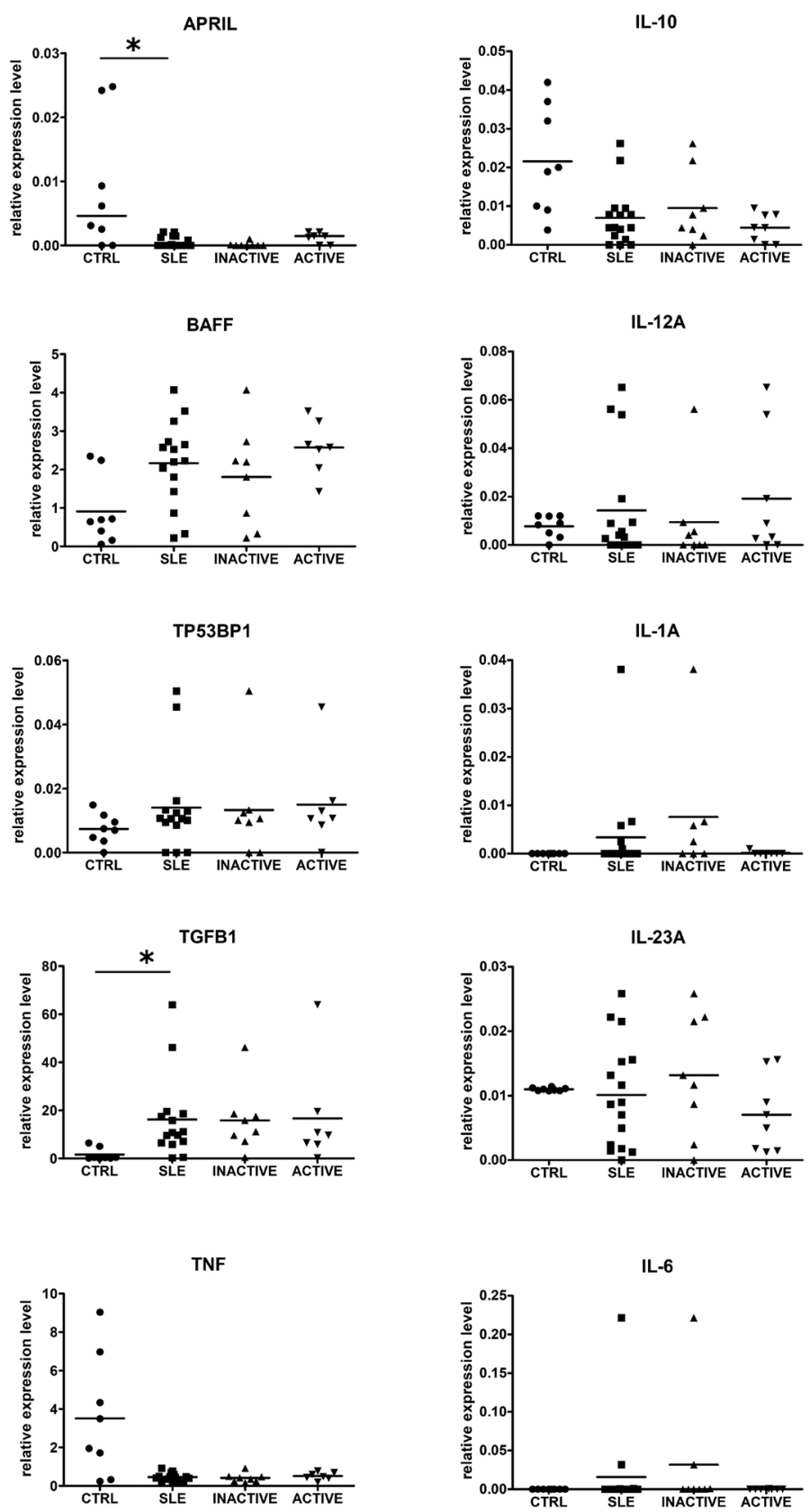

Figure 3. Changes in mRNA expression in mDCs from SLE patients.

Expression levels of analyzed genes are presented in relation to HPRT expression in mDCs, as determined by qPCR. Data in graphs represent individual distribution of data points and the median value per group.

DNA methyltransferase 1 (DNMT1) is essential for propagating DNA methylation patterns during replication, while methyl CpG-binding domain 2 (MBD2) is related to the demethylation effect (Liu et al., 2011) and is believed to be crucial for optimal function of CD $11 \mathrm{c}^{+}$ DCs. While no difference has been found in expression of DNMT1, mDCs from SLE patients showed an increased expression of $M B D 2$ when compared to healthy people ( $p=0.024$, Mann-Whitney U test, Fig. 3).

Among cytokine-related transcripts, only TGFB1 encoding an anti-inflammatory cytokine was upregulated in mDCs ( $p=0.001$, Mann-Whitney U test, Fig. 3), and pDCs ( $p=0.002$, Mann-Whitney U test, Fig. 4) from SLE patients. The remaining group of cytokines (TNF,
IFNG, IL-10, IL-12A, IL-1A, IL-23A, IL-O) showed no differences in gene expression between patients and control individuals (Fig. 3 and 4).

Expression of PD-L1 was significantly increased in both, the mDCs ( $p=0.02$, Mann-Whitney U test, Fig. 3), and pDCs ( $p=0.023$, Mann-Whitney U test, Fig. 4) from SLE patients.

We also found significant correlations between gene expression in DCs from SLE patients and levels of some serum components, which are presented in Table 4.

Expression of the TNF gene in $\mathrm{mDCs}$ was negatively correlated with the $\mathrm{C} 3$ serum level $(\mathrm{r}=-0.67, p<0.05$, Spearman Rank Correlation test). In pDCs, it was negatively correlated with both, the C3 ( $\mathrm{r}=-0.69, p<0.05$, 

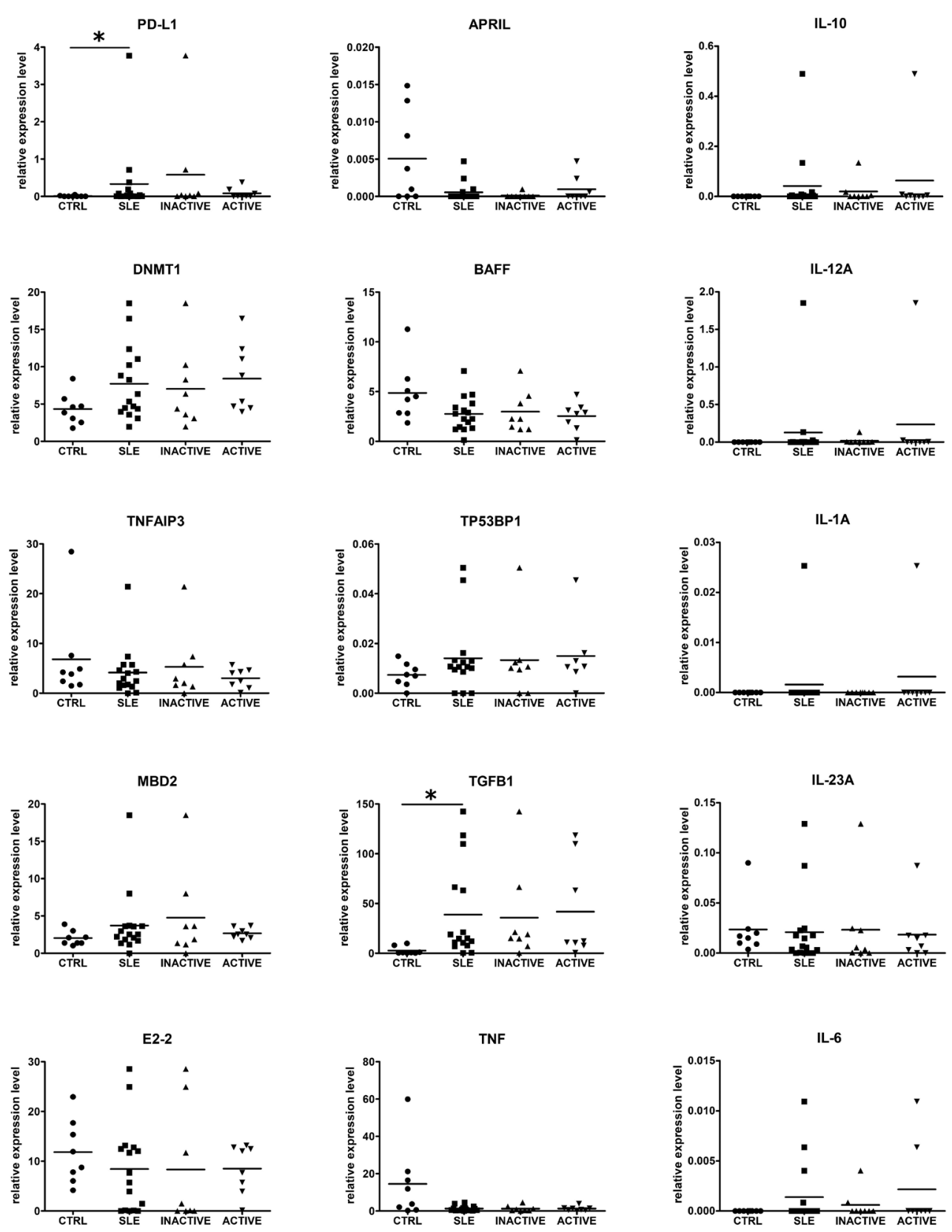

Figure 4. Changes in mRNA expression in pDCs from SLE patients.

Expression levels of analyzed genes are presented in relation to HPRT expression in pDCs, as determined by qPCR. Data in graphs represent individual distribution of data points and the median value per group.

Spearman Rank Correlation test) and C4 levels ( $\mathrm{r}=-0.53$, $p<0.05$, Spearman Rank Correlation test). Expression of the IRF5 gene in pDCs was negatively correlated with the $\mathrm{C} 4$ serum level $(\mathrm{r}=-0.53, p<0.05$, Spearman Rank Correlation test). APRIL expression in mDCs was also negatively correlated with the C4 levels $(\mathrm{r}=-0.53, p<0.05$, Spearman Rank Correlation test Table 4)

Importantly, we have found no significant differences in gene expression between patients with ACTIVE SLE and INACTIVE SLE. Also, presence of a treatment had no significant influence on any of the parameters.

The serum level of anti-dsDNA antibodies was positively correlated with expression of APRIL ( $\mathrm{r}=0.79$, Spearman Rank Correlation test) and BAFF ( $\mathrm{r}=0.62$, $p<0.05$, Spearman Rank Correlation test), and negatively correlated with ID2 ( $\mathrm{r}=-0.59, p<0.05$, Spearman Rank Correlation test), MBD2 ( $\mathrm{r}=-0.65$, Spearman Rank Correlation test), andTGFB1 ( $\mathrm{r}=-0.57$, Spearman Rank Correlation test) in mDCs. The serum level of anti-dsDNA antibodies was positively correlated with expression of APRIL in pDCs as well ( $\mathrm{r}=0.58$, Spearman Rank Correlation test, Table 4). Expression of PD-L1 in pDCs was negatively correlated with the level of anti-dsDNA antibodies ( $\mathrm{r}=-0.61$, Spearman Rank Correlation test).

\section{Changes in levels of soluble receptors for cytokines}

Having compared the acquired Luminex assay data between all SLE patients and the control group, we 
Table. 4. Associations between serum components and analysed immune cell populations.

\begin{tabular}{|c|c|c|c|c|c|c|c|c|c|c|}
\hline \multirow{2}{*}{ Serum component } & \multicolumn{10}{|c|}{ mDC genes } \\
\hline & APRIL & BAFF & ID2 & IL-1A & $\mathrm{IL}-6$ & IL-10 & MBD2 & TGFB1 & TNF & TNFAIP3 \\
\hline C3 & - & - & - & - & - & - & - & - & -0.67 & - \\
\hline C4 & -0.53 & - & - & - & - & - & - & - & - & - \\
\hline Anti-dsDNA Abs & 0.79 & 0.62 & -0.59 & - & - & - & -0.65 & -0.57 & - & - \\
\hline sIL-4R & 0.61 & - & - & - & - & 0.63 & - & -0.62 & - & - \\
\hline slL-6R & - & - & - & 0.77 & 0.63 & - & - & - & - & - \\
\hline sRAGE & - & - & - & - & - & - & - & - & 0.70 & - \\
\hline sTNFRI & - & - & - & - & - & - & - & - & - & -0.62 \\
\hline sVEGFR2 & - & - & 0.58 & - & - & - & - & - & - & - \\
\hline sVEGFR3 & - & - & - & 0.57 & - & - & - & - & - & - \\
\hline \multirow{2}{*}{ Serum component } & \multicolumn{10}{|c|}{ pDC genes } \\
\hline & APRIL & DNMT1 & E2-2 & $\mathrm{IL}-1 \mathrm{~A}$ & $\mathrm{IL}-6$ & IRF5 & MBD2 & PD-L1 & TNF & TNFAIP3 \\
\hline C3 & - & - & - & - & - & - & - & - & -0.69 & - \\
\hline C4 & - & - & - & - & - & -0.53 & - & - & -0.53 & -0.60 \\
\hline Anti-dsDNA Abs & 0.58 & - & - & - & - & - & - & -0.61 & - & - \\
\hline SIL-1R & 0.57 & - & - & 0.63 & - & - & - & - & - & - \\
\hline sIL1R a & - & - & - & - & - & - & - & - & 0.54 & - \\
\hline slL-4R & - & - & 0.64 & - & - & 0.59 & 0.70 & - & - & - \\
\hline slL-6R & - & - & - & - & - & - & - & - & 0.58 & - \\
\hline sVEGRF1 & - & -0.52 & - & - & 0.62 & - & - & - & - & - \\
\hline sVEGFR3 & - & - & - & - & 0.53 & - & - & - & - & - \\
\hline
\end{tabular}

Data shown in the table are presented as the values of correlation coefficients from the Spearman Rank Correlation test (r). The table represents only statistically significant associations between the analysed parameters (gene expression and sera proteins). The gene expression ratio was correlated with serum components shown as either $\mathrm{g} / \mathrm{l}(\mathrm{C} 4, \mathrm{C} 4$, anti-dsDNA Abs) or pg/ml (soluble cytokine receptors). Presented values are statistically significant values with $p<0.05$.

found no differences in serum levels of 13 soluble receptors (Table 3). Similar comparison of data for each SLE group, ACTIVE SLE and INACTIVE SLE, with control individuals, detected no significant differences. Based on that we may state that regardless of the disease activity, the levels of soluble receptors for cytokines do not differ in comparison to healthy volunteers. The only significant dissimilarity was found in terms of the sEGFR levels between patients with active disease and the ones in the remission phase.

Interestingly, we found some correlations between serum levels of soluble receptors for cytokines and gene expression in $\mathrm{mDCs}$ and $\mathrm{pDCs}$ from SLE patients (Table 4). The serum level of sIL-4R was positively correlated with APRIL ( $\mathrm{r}=0.61, p<0.05$, Spearman Rank Correlation test) and IL-10 ( $\mathrm{r}=0.63, p<0.05$, Spearman Rank Correlation test) gene expression in mDCs. It was also positively correlated with E2-2 $(\mathrm{r}=0.63, p<0.05$, Spearman Rank Correlation test), IRF5 ( $\mathrm{r}=0.59, p<0.05$, Spearman Rank Correlation test), and MBD2 ( $r=0.70$, $p<0.05$, Spearman Rank Correlation test, Table 4) gene expression in $\mathrm{pDCs}$.

The serum level of sIL-6R was positively correlated with IL-1A ( $\mathrm{r}=0.77, p<0.05$, Spearman Rank Correlation test) and IL-6 ( $\mathrm{r}=0.63, p<0.05$, Spearman Rank Correlation test) gene expression in mDCs. It was positively correlated only with TNF gene expression in pDCs $(\mathrm{r}=0.58$, Spearman Rank Correlation test, Table 4).
A positive correlation was found between sVEGFR2 and ID2 expression in $\mathrm{mDCs}(\mathrm{r}=0.58, p<0.05$, Spearman Rank Correlation test). The level of VEGFR1 was negatively correlated with gene expression of DNMT1 $(\mathrm{r}=-0.52, p<0.05$, Spearman Rank Correlation test) and positively correlated with IL-6 ( $\mathrm{r}=0.62, p<0.05$, Spearman Rank Correlation test) in pDCs. The level of VEGFR3 was positively correlated with gene expression of IL$1 A$ ( $\mathrm{r}=0.57, p<0.05$, Spearman Rank Correlation test $)$ in mDCs, as well as with IL-6 ( $\mathrm{r}=0.53$, Spearman Rank Correlation test, Table 4$)$ in pDCs.

The serum level of sRAGE was positively correlated with gene expression of TNF in mDCs $(r=0.7, p<0.05$, Spearman Rank Correlation test).

\section{DISCUSSION}

The role of dendritic cells in the development of SLE has been widely studied. These studies focused on altered DC subset frequency and localization, overactivation of $\mathrm{mDCs}$ and $\mathrm{pDCs}$, and functional defects in DCs, which may help to find new therapies targeting DC. The precise aetiology of SLE still remains unclear when we consider its diverse clinical manifestations. While there is an agreement that DCs play a key role in its development and there is data showing that the frequency, composition, and phenotype of DCs in SLE patients differ 
from those of healthy individuals, the results are often conflicting (Klarquist et al., 2016). This disagreement might be caused by the presence of many differences in the disease activity and manifestations, the variations in analytical parameters, and that the various drugs influence DC development and phenotype.

According to our study, the general frequencies of $\mathrm{mDC}$ and $\mathrm{pDC}$ subpopulations were not strongly affected by the course of the disease. According to Klarquist and others (Klarquist et al., 2016), studies revealed that $\mathrm{mDC}$ frequencies can be reduced, normal, and increased in SLE patients. Similarly, pDC levels were found to be unaffected, decreased, or increased. Some authors show that decreased frequencies of $\mathrm{pDCs}$ or $\mathrm{mDCs}$ are most often associated with an active disease. It is probable that all authors are right. First of all, it is difficult to compare results between laboratories. Also, SLE patients recruited by different authors differ in terms of severity of clinical symptoms and organ involvement, not to mention the medications used and the disease duration. All of these factors can influence frequencies of DCs. Organ involvement is of particular importance - DCs can reside in or be recruited into the affected tissues (Farkas et al., 2001; Fiore et al., 2008). Thus, cells detected in the blood may not reflect the actual proportions in lupus.

We also saw that patients presented an increased rate of activated $\mathrm{mDCs}$ identified as $\mathrm{CD} 80^{+} \mathrm{CD} 83^{+}$cells, especially those with INACTIVE SLE. CD83 is an activation marker of antigen presenting cells. Jin and others (Jin et al., 2008) demonstrated that CD83 expression decreases in mDCs from SLE patients, particularly those with an active disease, which would suggest that their function is impaired. However, impaired clearance of apoptotic blebs in tissues of SLE patients induces maturation of mDCs (Fransen et al., 2010), which would explain, why we see higher percentage of $\mathrm{CD} 80^{+} \mathrm{CD} 83^{+}$ cells in SLE patients.

We also observed that transcription patterns in $\mathrm{mDCs}$ and pDCs were affected by the disease. Moreover, subpopulation specific changes in gene expression in DCs were also observed. These changes were in accordance with other studies suggesting that interferon regulatory factors play a vital role in the autoimmune dendritic cells' dysregulation (Baccala et al., 2013; Sichien et al., 2016). mDCs and pDCs were found to have an increased level of IRF5 mRNA, while pDCs had an additionally increased expression of IRF1, a critical signalling protein in the interferon pathway (Zhang et al., 2015). Changes in IRF5 and IRF1 were independent of the disease activity. Upregulation of IRFs corresponds to their role in the development of a particular subset of dendritic cells. Expression of IRF5, a SLE susceptibility gene (RuizLarrañaga et al., 2016) crucial for inflammatory cytokine production (Cao \& Liu, 2007), could indirectly lead to the increased levels of soluble receptors (especially sIL1Ralpha, sIL-4R, sIL-6R, sTNFRI/II). However, we saw no significant changes in those receptors in our study group.

Product of the E2-2 gene is required for specific pDC gene expression and regulates transcription of $I R F 8$ in this cell population (Fransen et al., 2010; Baccala et al., 2013). Contrary, ID2 is an inhibitor of pDC development (Lin et al., 2015), probably through its ability to block E2-2 action. In our study, the E2-2 expression was higher in pDCs when compared to mDCs. However, only mDCs were characterized by upregulation of E2-2 when compared to healthy controls. An increased E2-2 expression, simultaneously with decreased expression of ID2 in mDCs which was negatively correlated with the level of anti-dsDNA antibodies, suggests that both genes could be involved in an increased activity of mDCs in SLE patients.

In our study, we observed a moderate upregulation of MBD2 only in mDCs. Product of the MBD2 gene is involved in the demethylation effect (Liu et al., 2011) and is believed to be crucial for optimal functioning of mDCs $\left(\mathrm{CD} 11 \mathrm{c}^{+}\right)$. Together with DNMT1, it is involved in epigenetic mechanisms that can influence chromosomal stability and gene expression (Liu et al., 2011). However, product of the DNMT1 gene is responsible for maintenance of the DNA methylation pattern during cell division (Miao et al., 2014; Picascia et al., 2015). This methylation imprint can be recognized by $M B D 2$ (Cook et al., 2015). The MBD2 "readout" of the methylation pattern in the promoter region of the target gene can lead to posttranscriptional modifications resulting in changed expression of the gene (Xu et al., 2018). In SLE patients, upregulation of MBD2 is related to enhanced neurological complications. Literature data on neurological disorders revealed a similar transcriptional dysregulation in PBMCs from patients with secondary progressive multiple sclerosis (Fagone et al., 2016).

In SLE, mDCs present autoantigens to $\mathrm{T}$ and $\mathrm{B}$ cells, and stimulate production of autoantibodies and proinflammatory cytokines, thus exacerbating the autoimmune process. Also, they are one of the cells responsible for production of the $B$ cell-activating factors, including APRIL and BAFF. BAFF promotes survival of $\mathrm{B}$ cells from the transitional stage of their development onwards. Acting at a later stage, the APRIL protein is responsible for modulation of function and survival of antigen-experienced B cells (Rauch et al., 2009; Samy et al., 2017) . Therefore, both factors seem to be key players in the humoral response as the BAFF/APRIL axis is part of the immune cell activation cascade, and if dysregulated may result in autoimmunity (Samy et al., 2017). As we have recently demonstrated, $B A F F$ gene expression in B cells of SLE patients is very low when compared to healthy controls, while APRIL gene expression is higher in patients with active SLE, especially those with renal insufficiency (Wardowska et al., 2020). In the study presented here, we did not find any changes in $B A F F$ expression in DCs, however, APRIL expression was significantly increased in $\mathrm{mDCs}$, which indicates that these cells can be an important source of APRIL. Also, its expression was positively correlated with anti-dsDNA antibodies and sIL-4R, and negatively correlated with the C4 levels. Similar observations were made for $B A F F$, which was also correlated with the level of anti-dsDNA antibodies.

These results confirm the important role of $\mathrm{mDCs}$ related to the production of both very important proteins involved in SLE development. In SLE, the serum BAFF and APRIL levels are often elevated, which explains increased activity of $\mathrm{B}$ cells that produce autoantibodies. This increased concentration of both proteins correlates with the disease severity (Treamtrakanpon et al., 2012; Salazar-Camarena et al., 2016) and the levels of pathogenic autoantibodies (Bosello et al., 2008; McCarthy et al., 2013). Therefore, biological agents (e.g. belimumab) that can block their activity are very useful in SLE treatment. In a previous study, we have shown that there were no significant differences in serum levels of BAFF in SLE patients when compared to healthy controls, while the APRIL levels were even significantly decreased (Wardowska et al., 2020). As we suggested earlier, it is also possible that an increased APRIL gene expression in $\mathrm{B}$ cells of SLE patients (Wardowska et al., 2020), as well as 
in mDCs, as demonstrated here, is the result of feedback in response to urinary protein loss which is a phenomenon often described in SLE (Phatak et al., 2017).

Last but not least, we should mention the changes in PD-L1 and TGFB1 genes that were up-regulated in both, mDCs and pDCs. Product of PD-L1 is a ligand for programmed death (PD)-1 receptors, which are also studied in SLE development. According to Mozaffarian et al. (Mozaffarian et al., 2008), both - mDCs and macrophages from patients with active SLE, fail to up-regulate PD-L1 and express this protein only during disease remissions. In our study, we saw that expression of the PD-L1 gene is increased in mDCs, as well as in pDCs, regardless of the disease activity. In our previous study, we saw that PD-L1 gene expression was also increased in B cells from SLE patients with renal insufficiency (Wardowska et al., 2020). Ou et al. (Ou et al., 2012) showed that PD-L1 expression in SLE monocytes is regulated by opposing actions of TNF- $\alpha$ and TGF- $\beta$ - TNF $\alpha$ stimulates PD-L1 production, while TGF- $\beta$ inhibits. At the same time, these authors demonstrated that PBMCs from SLE patients produce more TGF after stimulation than those of healthy people, while other authors showed that TGF- $\beta$, an anti-inflammatory cytokine, is found to be decreased in SLE patients, especially those with high disease activity and organ damage (Rashad et al., 2019). Other authors also showed that T lymphocytes from SLE patients do not produce TGF- $\beta 1$ (Kohut et al., 2009). Therefore, it seems reasonable to conclude that it is necessary to simultaneously determine expression of both genes in different populations of immune cells, with the parallel assessment of serum cytokines in patients with SLE.

The study presented here has its limitations related to the therapeutic scheme and disease duration time. All of the patients enrolled in this study have been affected by the disease at least for 18 months. Therefore, it was necessary to analyse whether the type of treatment could affect the parameters studied here. Standard management of SLE comprises of glucocorticosteroids, immunosuppressants and anti-malarial drugs in various combinations. Each of these groups interferes with the immune system activity. Glucocorticoids are potent inhibitors of the inflammatory processes, acting through specific mechanisms: genomic and non-genomic, leading to the general decrease in the immune system activity (Deng et al., 2019). In our study, all patients except one, received glucocorticosteroids. Therefore, we are not able to assess to what extent they might have affected the results obtained.

Nine patients enrolled in this study also received immunosuppressing drugs (azathioprine, cyclosporine, or mycophenolate mofetil) and seven were treated with hydroxychloroquine (anti-malarial drugs). Immunosuppressive treatment, in general, mainly acts on the proliferating cells, such as $\mathrm{T}$ and $\mathrm{B}$ cells, and stops their differentiation and expansion. Hydroxychloroquine (HCQ) modifies activity of the antigen-presenting cells (DCs and monocytes) (van der Heijden et al., 2019). In the light of given data, HCQ could have the greatest impact on our results. Nevertheless, we did not observe any significant changes in patients treated with HCQ. Probably, HCQ itself does not influence the phenotype of DCs or the gene transcription. Its activity is mainly related to the ability to increase the intracytoplasmic $\mathrm{pH}$ and to thereby preventing acidification and maturation of endosomes, which results in impaired production of TNF and IFN (Sacre et al., 2012).
Also, we actually did not find any relationship between the disease activity and the parameters studied. This may mean that the treatment used has no effect on the expression of most genes, even in the case of glucocorticoids themselves whose activity is associated with transcription modulation in many cells.

In summary, the above results confirm significant disturbances in the functioning of $\mathrm{mDCs}$ in SLE. While majority of authors pay more attention to the role of pDCs in the disease development through increased IFN production, greater activation of $\mathrm{mDCs}$ is important for presentation of the autoantigens. In our study, expression of many genes in mDCs, including APRIL, E2-2, $M B D 2$ or $P D-L 1$, was not only significantly increased in SLE patients, but it was also correlated with anti-dsDNA antibody concentrations, complement components and soluble receptors for many cytokines. We are aware that the study group was not numerous. However, in many cases, significant differences in the selected parameters between the SLE patients and healthy people suggest that we need to continue molecular studies of mDCs and pDCs cells not only to understand their role in SLE development, but also to find new biological drugs. In the future, a study with larger groups should allow to find more relationships between gene expression in dendritic cells and clinical manifestations of the disease.

\section{Author Contributions}

AW designed the study, obtained funding, did all experiments, analysed the clinical and experimental data, and wrote the manuscript; $\dot{Z} S$ collected clinical material; ZS, ZZ analysed clinical data; MP analysed the clinical and experimental data. KAL analysed experimental data, and revised the manuscript. MP revised the manuscript. All of the authors approved the final version of the manuscript.

\section{Acknowledgments}

The authors would like to thank Prof. Piotr Trzonkowski from the Department of Medical Immunology, Medical University of Gdansk, for providing access to needed equipment.

\section{Conflicts of Interest}

The authors declare no conflict of interest.

\section{REFERENCES}

Baccala R, Gonzalez-Quintial R, Blasius AL, Rimann I, Ozato K, Kono DH, Beutler B, Theofilopoulos AN (2013) Essential requirement for IRF8 and SLC15A4 implicates plasmacytoid dendritic cells in the pathogenesis of lupus. Proc. Natl. Acad. Sci. 110: 2940-2945. https://doi.org/10.1073/pnas.1222798110

Bennett L. Palucka AK, Arce E, Cantrell V, Borvak J, Banchereau J, Pascual V (2003) Interferon and Granulopoiesis Signatures in Systemic Lupus Erythematosus Blood. J. Exp. Med. 197: 711-723. https://doi.org/10.1084/jem.20021553

Bosello S, Youinou P, Daridon C, Tolusso B, Bendaoud B, Pietrapertosa D, Morelli A, Ferraccioli G (2008) Concentrations of BAFF correlate with autoantibody levels, clinical disease activity, and response to treatment in early rheumatoid arthritis. J. Rheumatol. 35: 1256-1264. http://www.ncbi.nlm.nih.gov/pubmed/18528969

Cao W, Liu YJ (2007) Innate immune functions of plasmacytoid dendritic cells. Curr. Opin. Immunol. 19: 24-30. https://doi. org/10.1016/j.coi.2006.11.004

Chan VSF, Nie YJ, Shen N, Yan S, Mok MY, Lau CS (2012) Distinct roles of myeloid and plasmacytoid dendritic cells in systemic lupus erythematosus. Autoimmun. Rev. 11: 890-897. https://doi. org/10.1016/j.autrev.2012.03.004

Collin M, Bigley V (2018) Human dendritic cell subsets: an update. Immunology 154: 3-20. https://doi.org/10.1111/imm.12888 
Cook PC, Owen H, Deaton AM, Borger JG, Brown SL, Clouaire T, Jones G-R, Jones LH, Lundie RJ, Marley AK, et al. (2015) A dominant role for the methyl-CpG-binding protein Mbd2 in controlling Th2 induction by dendritic cells. Nat. Commun. 6: 6920. https://doi. org $/ 10.1038 /$ ncomms 7920

Deng J, Chalhoub NE, Sherwin CM, Li C, Brunner HI (2019) Glucocorticoids pharmacology and their application in the treatment of childhood-onset systemic lupus erythematosus. Semin. Arthritis. Rheum. 49: 251-259. https://doi.org/10.1016/j.semarthrit.2019.03.010

Devi K, SP, Anandasabapathy N (2017) The origin of DCs and capacity for immunologic tolerance in central and peripheral tissues. Semin. Immunopathol. 39: 137-152. https://doi.org/10.1007/s00281016-0602-0

Fagone P, Mangano K, Di Marco R, Touil-Boukoffa C, Chikovan T, Signorelli S, Lombardo GAG, Patti F, Mammana S, Nicoletti F (2016) Expression of DNA methylation genes in secondary progressive multiple sclerosis. J. Neuroimmunol. 290: 66-69. https://doi. org/10.1016/j.jneuroim.2015.11.018

Farkas L, Beiske K, Lund-Johansen F, Brandtzaeg P, Jahnsen FL (2001) Plasmacytoid Dendritic Cells (Natural Interferon- $\alpha / \beta$-Producing Cells) Accumulate in Cutaneous Lupus Erythematosus Lesions. Am. J. Pathol. 159: 237-243. https://doi.org/10.1016/S00029440(10)61689-6

Fiore N, Castellano G, Blasi A, Capobianco C, Loverre A, Montinaro V, Netti S, Torres D, Manno C, Grandaliano G, et al. (2008) Immature myeloid and plasmacytoid dendritic cells infiltrate renal tubulointerstitium in patients with lupus nephritis. Mol. Immunol. 45: 259-265. https://doi.org/10.1016/j.molimm.2007.04.029

Fransen JH, Vlag J, Ruben J, Adema GJ, Berden JH, Hilbrands LB (2010) The role of dendritic cells in the pathogenesis of systemic lupus erythematosus. Arthritis. Res. Ther. 12: 207. https://doi. org/10.1186/ar2966

Furie R, Werth VP, Merola JF, Stevenson L, Reynolds TL, Naik H, Wang W, Christmann R, Gardet A, Pellerin A, et al. (2019) Monoclonal antibody targeting BDCA2 ameliorates skin lesions in systemic lupus erythematosus. J. Clin. Invest. 129: 1359-1371. https://doi. org/10.1172/JCI124466

Gladman DD, Ibañez D, Urowitz MB (2002) Systemic lupus erythematosus disease activity index 2000. J. Rheumatol. 29: 288-291. Available at: http://www.ncbi.nlm.nih.gov/pubmed/11838846

van der Heijden EH, Hartgring SA, Kruize AA, Radstake TR, van Roon JA (2019) Additive immunosuppressive effect of leflunomide and hydroxychloroquine supports rationale for combination therapy for Sjögren's syndrome. Expert. Rev. Clin. Immunol. 15: 801-808. https://doi.org/10.1080/1744666X.2019.1624527

Henriques A, Inês L, Carvalheiro T, Couto M, Andrade A, Pedreiro S, Laranjeira P, Morgado JM, Pais ML, da Silva JAP, et al. (2012) Functional characterization of peripheral blood dendritic cells and monocytes in systemic lupus erythematosus. Rheumatol. Int. 32: 863869. https://doi.org/10.1007/s00296-010-1709-6

Honarpisheh M, Köhler P, von Rauchhaupt ELM (2018) The involvement of MicroRNAs in modulation of innate and adaptive immunity in systemic lupus erythematosus and lupus nephritis. J. Immunol. Res. May 8: 4126106. https://doi.org/10.1155/2018/4126106

van den Hoogen LL, Rossato M, Lopes AP, Pandit A, Bekker CPJ, Fritsch-Stork RDE, van Roon JAG, Radstake TRDJ (2018) microRNA downregulation in plasmacytoid dendritic cells in interferonpositive systemic lupus erythematosus and antiphospholipid syndrome. Rheumatology. 57: 1669-1674. https://doi.org/10.1093/rheumatology/key159

Jaiswal H, Kaushik M, Sougrat R, Gupta M, Dey A, Verma R, Ozato K, Tailor P (2013) Batf3 and Id2 have a synergistic effect on Irf8directed classical CD8 + dendritic cell development. J. Immunol. 191: 5993-6001. https://doi.org/10.4049/jimmunol.1203541

Jin O, Kavikondala S, Sun L, Fu R, Mok MY, Chan A, Yeung J, Lau CS (2008) Systemic lupus erythematosus patients have increased number of circulating plasmacytoid dendritic cells, but decreased myeloid dendritic cells with deficient CD83 expression. Lupus. 17: 654-662. https://doi.org/10.1177/0961203308089410

Klarquist J, Zhou Z, Shen N, Janssen EM (2016) Dendritic cells in systemic lupus erythematosus: from pathogenic players to therapeutic tools. Mediators Inflamm. 2016: 1-12. https://doi. org/10.1155/2016/5045248

Klavdianou K, Lazarini A, Fanouriakis A (2020) Targeted biologic therapy for systemic lupus erythematosus: emerging pathways and drug pipeline. BioDrugs. 34: 133-147. https://doi.org/10.1007/ s40259-020-00405-2

Kohut E, Hajdu M, Gergely P, Gopcsa L, Kilián K, Pálóczi K, Kopper L, Sebestyén A (2009) Expression of TGFß1 and its signaling components by peripheral lymphocytes in systemic lupus erythematosus. Pathol. Oncol. Res. 15: 251-256. https://doi.org/10.1007/ s12253-008-9119-8

Lin Q, Chauvistré H, Costa IG, Gusmao EG, Mitzka S, Hänzelmann S, Baying B, Klisch T, Moriggl R, Hennuy B, Smeets H, Hoffmann K, Benes V, Seré K, Zenke M (2015) Epigenetic program and tran- scription factor circuitry of dendritic cell development. Nucleic Acids Res. 43: 9680-9693. https://doi.org/10.1093/nar/gkv1056

Liu C, Ou T, Wu C, Li R, Lin Y, Lin C, Tsai W, Liu H, Yen J (2011) Global DNA methylation, DNMT1, and MBD2 in patients with systemic lupus erythematosus. Lupus. 20: 131-136. https://doi. org/10.1177/0961203310381517

Mackern-Oberti JP, Llanos C, Riedel CA, Bueno SM, Kalergis AM (2015) Contribution of dendritic cells to the autoimmune pathology of systemic lupus erythematosus. Immunology. 146: 497-507. https:// doi.org/10.1111/imm.12504

Macri C, Pang ES, Patton T, O'Keeffe M (2018) Dendritic cell subsets. Semin. Cell. Dev. Biol. 84: 11-21. https://doi.org/10.1016/j.semcdb.2017.12.009

McCarthy EM, Lee RZ, Ni Gabhann J, Smith S, Cunnane G, Doran MF, Howard D, O'Connell P, Kearns G, Jefferies CA (2013) Elevated B lymphocyte stimulator levels are associated with increased damage in an Irish systemic lupus erythematosus cohort. Rheumatology 52: 1279-1284. https://doi.org/10.1093/rheumatology/ket120

Miao CG, Yang JT, Yang YY, Du CL, Huang C, Huang Y, Zhang L, Lv XW, Jin Y, Li J (2014) Critical role of DNA methylation in the pathogenesis of systemic lupus erythematosus: new advances and future challenges. Lupus 23: 730-742. https://doi. org/10.1177/0961203314527365

Mozaffarian N, Wiedeman AE, Stevens AM (2008) Active systemic lupus erythematosus is associated with failure of antigen-presenting cells to express programmed death ligand-1. Rheumatology (Oxford, England.) 47: 1335-1341. https://doi.org/10.1093/rheumatology/ $\operatorname{ken} 256$

Ou JN, Wiedeman AE, Stevens AM (2012) TNF- $\alpha$ and TGF- $\beta$ counter-regulate PD-L1 expression on monocytes in systemic lupus erythematosus. Sci. Rep. 2: 295. https://doi.org/10.1038/srep00295

Pellerin A, Otero K, Czerkowicz JM, Kerns HM, Shapiro RI, Ranger AM, Otipoby KL, Taylor FR, Cameron TO, Viney JL, Rabah D (2015) Anti-BDCA 2 monoclonal antibody inhibits plasmacytoid dendritic cell activation through Fc-dependent and Fc-independent mechanisms. EMBO Mol. Med. 7: 464-476. https://doi. org/10.15252/emmm.201404719

Phatak S, Chaurasia S, Mishra SK, Gupta R, Agrawal V, Aggarwal A, Misra R (2017) Urinary B cell activating factor (BAFF) and a proliferation-inducing ligand (APRIL): potential biomarkers of active lupus nephritis. Clin. Exp. Immunol. 187: 376-382. https://doi. org/10.1111/cei.12894

Picascia A, Grimaldi V, Pignalosa O, De Pascale MR, Schiano C, Napoli C (2015) Epigenetic control of autoimmune diseases: From bench to bedside. Clin. Immunol. 157: 1-15. https://doi. org/10.1016/j.clim.2014.12.013

Rashad NM, El-Shabrawy RM, Said D, El-Shabrawy SM, Emad G (2019) Serum levels of transforming growth factor beta-1 (TGF- $\beta 1$ ) as an early no invasive marker for diagnosis of lupus nephritis in systemic lupus erythematosus patients. Egypt. J Immunol. 26: 31-42. http://www.ncbi.nlm.nih.gov/pubmed/31332994

Rauch M, Tussiwand R, Bosco N, Rolink AG (2009) Crucial role for BAFF-BAFF-R signaling in the survival and maintenance of mature B cells. PLoS One. https://doi.org/10.1371/journal.pone.0005456

Romero-Diaz J, Isenberg D, Ramsey-Goldman R (2011) Measures of adult systemic lupus erythematosus: updated version of British Isles Lupus Assessment Group (BILAG 2004), European Consensus Lupus Activity Measurements (ECLAM), Systemic Lupus Activity Measure, Revised (SLAM-R), Systemic Lupus Activity Questi. Arthritis Care. Res (Hoboken). 63 (Suppl 1): S37-S46. https://doi. org/10.1002/acr.20572

Ruiz-Larrañaga O, Migliorini P, Uribarri M, Czirják L, Alcaro MC, del Amo J, Iriondo M, Manzano C, Escorza-Treviño S, Estonba A (2016) Genetic association study of systemic lupus erythematosus and disease subphenotypes in European populations. Clin. Rheumatol. 35: 1161-1168. https://doi.org/10.1007/s10067-016-3235-8

Sacre K, Criswell LA, McCune JM (2012) Hydroxychloroquine is associated with impaired interferon-alpha and tumor necrosis factor-alpha production by plasmacytoid dendritic cells in systemic lupus erythematosus. Arthritis Res. Ther. 14: R155. https://doi.org/10.1186/ ar3895

Sakata K, Nakayamada S, Miyazaki Y, Kubo S, Ishii A, Nakano K, Tanaka Y (2018) Up-regulation of TLR7-mediated IFN- $\alpha$ production by plasmacytoid dendritic cells in patients with systemic lupus erythematosus. Front. Immunol. 9: 1957. https://doi.org/10.3389/ fimmu.2018.01957

Salazar-Camarena DC, Ortiz-Lazareno PC, Cruz A, Oregon-Romero E, Machado-Contreras JR, Muñoz-Valle JF, Orozco-López M, Marín-Rosales M, Palafox-Sánchez CA (2016) Association of BAFF, APRIL serum levels, BAFF-R, TACI and BCMA expression on peripheral B-cell subsets with clinical manifestations in systemic lupus erythematosus. Lupus 25: 582-592. https://doi. org/10.1177/0961203315608254

Samy E, Wax S, Huard B, Hess H, Schneider P (2017) Targeting BAFF and APRIL in systemic lupus erythematosus and other anti- 
body-associated diseases. Int. Rev. Immunol. 36: 3-19. https://doi.org /10.1080/08830185.2016.1276903

Sichien D, Scott CL, Martens L, Vanderkerken M, Van Gassen S, Plantinga M, Joeris T, De Prijck S, Vanhoutte L, Vanheerswynghels M, Van Isterdael G, Toussaint W, Madeira FB, Vergote K, Agace WW, Clausen BE, Hammad H, Dalod M, Saeys Y, Lambrecht BN, Guilliams M (2016) IRF8 Transcription factor controls survival and function of terminally differentiated conventional and plasmacytoid dendritic cells, respectively. Immunity 45: 626-640. https://doi. org/10.1016/j.immuni.2016.08.013

Treamtrakanpon W, Tantivitayakul P, Benjachat T, Somparn P, Kittikowit W, Eiam-ong S, Leelahavanichkul A, Hirankarn N, Avihingsanon Y (2012) APRIL, a proliferation-inducing ligand, as a potential marker of lupus nephritis. Arthritis Res. Ther. 14: R252. https:// doi.org/10.1186/ar4095

Wardowska A, Komorniczak M, Skoniecka A, Bułło-Piontecka B, Lisowska KA, Dębska-Ślizień MA, Pikuła M (2020) Alterations in peripheral blood B cells in systemic lupus erythematosus patients with renal insufficiency. Int. Immunopharmacol. 83: 106451. https:// doi.org/10.1016/j.intimp.2020.106451

Wu M, Assassi S (2013) The role of type 1 interferon in systemic sclerosis. Front. Immunol. 4: https://doi.org/10.3389/fimmu.2013.00266
Xu L, Sun WJ, Jia AJ, Qiu LL, Xiao B, Mu L, Li JM, Zhang XF, Wei Y, Peng C, Zhang DS, Xiang XG (2018) MBD2 regulates differentiation and function of Th17 cells in neutrophils-dominant asthma - HIF-1 $\alpha$. J. Inflamm. 15: 15. https://doi.org/10.1186/s12950-0180191-x

Yu CF, Peng WM, Oldenburg J, Hoch J, Bieber T, Limmer A, Hartmann G, Barchet W, Eis-Hübinger AM, Novak N (2010) Human plasmacytoid dendritic cells support Th17 cell effector function in response to TLR7 ligation. J. Immunol. 184: 1159-1167. https://doi. org/10.4049/jimmunol.0901706

Yu C, Gershwin ME, Chang C (2014) Diagnostic criteria for systemic lupus erythematosus: A critical review. J. Autoimmun. 48-49: 10-13. https://doi.org/10.1016/j.jaut.2014.01.004

Zeuner RA (2003) Response of peripheral blood mononuclear cells from lupus patients to stimulation by $\mathrm{CpG}$ oligodeoxynucleotides. Rheumatology. 42: 563-569. https://doi.org/10.1093/rheumatology/ keg191

Zhang Z, Shi L, Song L, Ephrem E, Petri M, Sullivan KE (2015) Interferon regulatory factor 1 marks activated genes and can induce target gene expression in systemic lupus erythematosus. Arthritis Rheumatol. 67: 785-796. https://doi.org/10.1002/art.38964 